\title{
Of light and limits: Philosophy matters
}

\author{
M. Elaine Botha1 \\ Emeritus Professor of Philosophy \\ Potchefstroom University for CHE \\ POTCHEFSTROOM \\ E-mail: ebotha@redeemer.on.ca
}

\section{Abstract \\ Of light and limits: Philosophy matters}

The deepest religious or faith commitments of a scholar enter into her theoretical work through the mediation of a (scientific) world view with its embedded philosophical assumptions about the subject matter. These philosophical assumptions are about the fundamental structure (order) of the world and imply assumptions about the nature of this order or structure. They are often embedded in theoretical notions that purport not to require any further grounding. As such they are thoroughly "religious". Metaphorical language and models often mediate these religious convictions. Christian scholarship implies critically weighing and assessing such assumptions and exposing their ideological or mythical nature.

The pivotal issue at the centre of the historical "turns" in philosophy of science appears to be diverse articulations of this locus of order. It is this perennial search for the elusive universal that surfaces in each of the "turns" in either philosophy or science which "turns" up with monotonous regularity in subject-related literature. All these "turns" seem to be bound in their point of departure to an epistemological position which could best still be described as that of modernity, i.e., anchored in the Enlightenment ideal of the subject-object divide and the belief that objective rational knowledge can be acquired, yet attempting to approach this rational objective knowledge via the medium of the knowing subject. This perennial search for the elusive universal reaches a dead-end in post-modernism. If Christian philosophy wants to shed light on this issue so central to the heart of theorizing, it needs to develop a dynamic understanding of the notion of law, order, limits and boundaries and the way such an understanding could inform the discussions concerning scientific realism and the end(s) of philosophy.

1 This article is based on the Inaugural address as professor of Philosophy at Redeemer University College, Ancaster, Ontario, Canada in February 1996. 
It is clear that convincing answers to these questions need to steer a course between "flabby" (Wayne Booth, 1986) pluralism which assumes that mere knowledge of a plurality of perspectives automatically assures immunity against the darknes, and "wild" (Bernstein, 1987) pluralism which rejects any possibility of communication between different positions and therefore gives up on the call to professing Christ even before we have started. I propose that the development of critical philosophical skills coupled with a responsible analysis of the theoretical infrastructure of theories requires solid philosophical grounding of both teachers and students and requires the recognition of philosophy's legitimate place in the curriculum. Why? Because philosophical systems and frameworks embody humankind's vision of what constitutes order and meaning in human life and reality, and because these systems reflect the deepest answers to the human predicament ... answers that need to be developed within the parameters set by two Biblical images, the image of light and God's covenantal law.

\section{Opsomming}

\section{Filosofiese verligting - In U Lig}

Die diepste religieuse geloosfoortuigings van 'n akademikus word via die bemiddeling van 'n (wetenskaplike/teoretiese) wêreldbeskouing wat gefundeer is in filosofiese vooronderstellings oor die faset van die werklikheid wat ondersoek word, binnegdra. Sodanige vooronderstellings herberg ook meestal die teoretiese paradigma se onderliggende beskouing oor die orde of struktuur van die werklikheid onder bespreking asook vooronderstellings wat nie deur die teoretiese paradigma of denker verder bevraagteken word nie. Juis die laasgenoemde trek verraai die diep religieuse karakter van dié tipe vooronderstellings.

Metaforiese taal en modelle is dikwels die draers van dergelike teoretiese en fundamenteel religieuse vooronderstellings. Christelike wetenskapsbeoefening impliseer die kritiese onthulling van hierdie vooronderstelings en die ontmaskering van ideologiese elemente daarin.

In die markante wendinge in die ideëgeskiedenis speel wisselende opvattinge oor die aard van die onderliggende orde in die werklikheid 'n deurslaggewende rol. Dit vorm deel van die nimmereindigende soeke na die ontwykende universalia wat met bykans vervelige reëlmaat in die ideëgeskiedenis opduik.

'n Nadere ondersoek na die aard van die wendinge in die geskiedenis van die denke laat blyk al spoedig dat die soeke gemotiveer en gedra word deur die diepliggende modernistiese Verligtingsdenke met sy dialektiese spanning tussen subjek en objek en die diepgesetelde geloof dat die rasionele vermoë van die subjek 
die bron van objektiwiteit is - 'n geloof wat uitmond in die subjektiwisme van die post-modernisme.

Christelike filosofie wat lig wil werp op hierdie impasse en die probleem van orde só sentraal in hierdie diskussie, sal dinamiese verantwoording moet doen oor hoe 'n Bybels verantwoorde visie op orde, struktuur en grense van die werklikheid ver-lig-ting kan bied. In hierdie diskussie behoort die Bybelse metafore van God se verbond met sy skepping en die liggewende rol van sy Woord-openbaring sowel in Skriftuur as in die natuur sentraal te staan.

\section{Preamble}

During the late sixties at the Free University in Amsterdam, while I was struggling to master the complex Christian philosophy of Herman Dooyeweerd, Amie van Wyk - theology student at the time - offered me some unsolicited advice: "If you want to understand any thinker's work albeit complex and dense, you need to discover the 'key' to the understanding of his oeuvre ...", he said. His advice was timely and to the point and I still owe him a debt of gratitude. Contemplating my own journey in Christian philosophy which intersected from time to time with Amie van Wyk's philosophical journey, I came to the conclusion that two strong Biblical images come to mind: the image of light and the image of the covenantal law. Because I believe Amie's work was developed within the same tradition, I would like to explore these Biblical themes for the development of Christian philosophy.

One of the most prevalent images in Scripture is the image of light, most powerfully embodied in the struggle of the two realms: the Kingdom of light and the Kingdom of darkness. This image of light - more specifically the light of God's Word, symbolized in the Jewish minora - the motto of the University of Potchefstroom is based on Psalm 36:10 (verse 9 in the New Revised Standard Version): "For with you is the fountain of life, in your light we see light ..." is the image that I would like to unpack in this paper. One of the earliest images of this Christian philosophy that opened a new world of understanding to me was the image of the white light refracted by a prism into the spectrum of colours of the rainbow. A simple image, to be sure, but a powerful one, suggesting the omnipresence of the light of God's revelation in the unity and diversity of creation, and its convergence in and reference to the central white light of the Morning Star, Jesus Christ, who is able to dispel the darkness in human lives, in theories and in culture.

The second Biblical image, the image of the Law or the Torah, is as prevalent as the first, the image of light. As the Morning Star drives darkness out, so the presence of the law reminds creation that the sovereign God is covenantally present and that in His law God is faithful 
to His creation. We notice this in the reliability of the force of gravity, the reliability of the change of seasons, but also in the predictability of natural phenomena. Obedient response to this law of the Lord is lifegiving. It is like being nourished by bread - the bread of Life.

Does philosophy really matter? Now, no one in his right mind would dare to ask: does cancer research matter? Or do budget cuts matter? Or does pollution matter? Does peacekeeping in Bosnia or Afghanistan matter? The answers to these questions are self-evident and obvious. But if the same question is framed concerning philosophy, the retort is soon heard: "Philosophy bakes no bread ...." to which one needs to respond unequivocally "... but, without philosophy no bread would ever have been baked!" To what extent the baking of bread in the widest metaphorical sense of the term is dependant on philosophy and its moorings in the Biblical images mentioned above, is what $I$ intend to explore in this paper.

In order to accomplish this, that is, to convince the reader that philosophy matters, I intend unpacking the images of light and limits, images which metaphorically set the parameters for the discussion of the nature of philosophy and its mediating role in the resolution of what the Dutch Calvinist philosopher, Van Riessen (1970), called "boundary problems". These are the difficult-to-resolve but perennially present issues related to both society and the sciences, the humanities and the social sciences with which humankind cannot refuse to deal. The answers to these questions come to expression in a world view which provides a way of looking at the world, at historical events and at one's own experiences. It helps one "make sense" of one's personal history and experiences, but also of the place one's own experiences and history share in the grand scale of events under God's providential guidance. Scholars deal with these problems too, but in a more general, perhaps universal, way. One such problem of special interest to scholarship is the question concerning order or structure or the quest for an understanding of "universals". The reason why this is important to scholars is that the search for order and the attempt to understand structure are at the heart of theorizing in all disciplines.

\section{Christian philosophy: Generating light}

If what Lesslie Newbigin says is true, that our society is no longer a secular society but has become a pagan society "far more resistant to the gospel than the pre-Christian paganism with which cross-cultural missions have been familiar" (Newbigin, 1996), then it is clear that in order to bring light into this pagan darkness Christian scholars will have to rethink their regular run-of-the-mill teaching and research imaginative- 
ly, creatively to seek ways and means to generate scholarly light in the darkness of such a pagan culture. This plea has so often been heard from both Reformed and Evangelical Christian circles that it most probably has become a resounding cliche (Plantinga, 1983; Wolterstorff, 1984; Henry, 1988). It would be superfluous and a waste of valuable time to belabour this point once more.

What this claim - of bringing light into the darkness of neo-pagan culture and scholarship - entails obviously needs to he fleshed out; it needs to be given body and limbs, and to take shape and develop in the scholarly enterprise in which the Lord has called His people to be storytellers of the great deeds of God to a new generation (Ps. 78; Seerveld, 1978). These stories inevitably involve issues that are at the core of human existence, the typical ultimate questions of human life and history. In this respect the issues dealt with in academic storytelling do not differ fundamentally from those of everyday human experience.

The ultimate frame of reference within which a Christian seeks to understand "his/her-story" is the relationship to God. This is looking at reality from the perspective of our religious or confessional commitment to the Lord whom we, as Reformational believers, confess is intimately concerned with every single aspect of our human lives and of creation. When we come to understand that the Lord Jesus Christ reigns over every single aspect of our human lives, we hopefully come to understand that the stories we have to tell about God's great deeds are related not only to our so-called "spiritual quest" but also to very ordinary aspects of human life and the miracle of God's providence and sustenance of our personal and communal lives - a pervading reality which qualifies the most mundane aspect of life as "spiritual".

\section{The pivotal role of philosophical storytelling}

Scholars who are committed to a holistic and integral understanding of faith and life also feel called to relate all their theoretical understanding of God's world to God's revelation in creation, in Scripture and in Jesus Christ. And this is what I would like to call "academic storytelling". A community of Christians with a Reformational view of the world needs artisans and shoemakers, butchers and artists, teachers, doctors, cooks, waiters, librarians and actors. But it also requires scholars who are committed to the theoretical understanding and interpretation of the wondrous works of God in creation, human life and history (Seerveld, 1978). This is the primary task of higher education where the discipline of philosophy, the act of philosophizing and the product of this activity "philosophy" - needs to fulfil a pivotal role. It is to this pivotal role of philosophical storytelling that I want to direct your attention. 
Philosophical stories and philosophical frameworks are at the core of all the manifold theoretical tales we tell our students and our peers in the halls of the academy. These philosophical stories provide the frameworks which shed or conceal light on the fundamental issues that all disciplines deal with, and specifically illuminate the limits, the boundaries of our subject matter, which are recognized or distorted by theories in the various disciplines. This is illustrated in the realm of psychology in the following quote from Sigmund Koch (1981:267):

Are we conceptually independent of philosophy? In a word, no. Most of our ideas have come from the 26 centuries of philosophy preceding the birth of our partition myth ... Though most of us have generated a vociferous rhetoric of independence in this century (especially those of behaviourist persuasion) one and all of necessity presupposed strong, if garbled philosophical commitments in the conduct of their work. Psychology is necessarily the most-philosophy sensitive discipline in the entire gamut of disciplines that claim empirical status. We cannot discriminate a so-called variable, pose a research question, choose or invent a method, project a theory, stipulate a psychotechnology without making strong presumptions of philosophical cast about the nature of our human subject matter presumptions that can be ordered to age-old contexts of philosophical discussion.

The reliance on and presence of philosophical assumptions also acknowledged in General Systems Theory, is a popular and prevalent approach present in Biology, Sociology, Social Work, Political Theory and various other disciplines. Weltman (1973:14) recognizes this but points to an even more fundamental characteristic of these philosophical assumptions. He calls the underlying structure of reality uncovered by Systems Theory "the ultimate reality", a reality which cannot be proved or disproved, but can only be stated. He says: "It is basically a metaphysical scheme which seeks to find in reality an ultimate orderliness above and beyond the ken of normal scientific methods of verification".

These metaphysical schemes harbour the ultimate commitments of theories, just as human stories are fundamentally the stories of human lives being lived within the parameters set by deep personal religious commitments. When Laszlo (1972), one of the expositors of Systems Theory, extols the virtues of Systems he exhorts us to revere "natural systems", he sees man and nature as an "... embracing network of dynamic, self-regulating and self-creative processes". He continues: "To know this is to admire the matrix out of which we arose, and to want to preserve what we are. We do not need elaborate fantasies or tales of legendary creation" (Laszlo, 1972:289). 
This quote obviously tells its own story. These are philosophical assumptions that undergird his Systems view of the world, philosophical assumptions that fulfil a very similar role to those that creation stories would within the life of a religious community or individual believer. In a Sociology textbook of the eighties by Sullivan et al. (1980) three sociological approaches, Functionalism, Conflict theory and Interactionism, are discussed, and there the inevitable presence of these philosophical assumptions in the theoretical description and explanation of social problems such as sex roles, divorce and drug abuse are articulated. These theories, the authors argue, propose radically different views of humankind, society, the nature of social problems and the possibilities of human intervention into these pathological states. These are three alternative sociological approaches that approximate the laws or regularities characteristic of the phenomena and each represents a different set of answers to the ultimate questions about nature, humankind and society - questions presupposed in most theories that deal with human behaviour. These answers are theoretical articulations of questions that we all answer in the stories of our lives, stories that come to expression in our world views.

What is the point of my story? It is a point already made both by Karl Popper (1972) and by post-modernist philosophy of science (Rouse, 1991). Popper (1972:346-347) pointed out that:

Science never starts from scratch, it can never be described as free from assumptions; for every instant it presupposes a horizon of expectations - yesterday's horizon of expectations, as it were. Today's science is built upon yesterday's science (and so it is the result of yesterday's searchlight); and yesterday's science, in turn, is based on the science of the day before. And the oldest scientific theories are built on pre-scientific myths, and these, in their turn, on still older expectations.

In the seventies Kisiel and Johnson (1974:147) characterized the "new" philosophy of science ushered in by the work of the Historical School in the Philosophy of Science (Kuhn, Hanson, Feyerabend, etc.) as "... the view that all of science is directed by historically determined global presuppositions ... which operate at a level deeper, more tacit and more comprehensive than that upon which theorems are determined by axioms".

These presuppositions are named differently by different authors: "paradigms" or "disciplinary matrix" (Kuhn, 1970; 1973; 1974), "ideals of natural order" (Collingwood, 1940), "fundamental patterns of expectations" (Spragens, 1973). Academic storytellers employ theories which assume or depend on implicit answers to what they regard to be the 
limits, the grounds, the foundations of their body of knowledge. Insofar as they do this - and I argue that they cannot escape doing this - they are involved in philosophical issues thoroughly laden with religious direction, a point which Roy Clouser has convincingly developed in his book, The Myth of Religious Neutrality (1991).

Scholars work with theories which try to give an account of the orderly nature of phenomena in order to understand the order for the phenomena they deal with. Theories are embedded in philosophies based on world views. One of the pivotal beliefs/assumptions in any theory and its accompanying (scientific) "world view" $\mathbf{2}$ is its understanding of the nature of this order. Once it is recognized that theories are embedded in philosophical frameworks (Spragens, 1973:123) and that philosophical frameworks can be discerned in the historical development of theories in a discipline, then the stage is set to deal with deeper philosophical issues. Perhaps this becomes apparent when one compares the continuity and difference between the intuitive (naive) everyday experience of regularities in the world and the experience of the same reality through the mediation of theories.

\section{The fact about facts of the matter}

The theoretical framework present in the theories of either Medicine or Music or any other discipline is not just an interpretation that is imposed on the facts or used to interpret the "facts", but it determines what is regarded as a "fact" at all. To be able to make the simple statement that something is a "fact" already implies the implementation of some system of categories in terms of which an observation organizes or makes sense of a perception. To be able to identify something as simple as a cube or a square or a circle implies that one has already interpreted the mere lines one perceives "to be something or other". Perhaps the best example of this is the set of categories used in Crystallography to classify crystals. Whether a stone set in a ring is seen to be a diamond or a piece of glass is certainly no interpretation added to the fact of the matter.

There is more to seeing than meets the eye ... This is true for everyday observation, which is conditioned by the categorical frameworks typical of our worldviews, and it is also true of scientific observation which is thoroughly theory-laden with the categories that theoretical frameworks prescribe. Let us call them "scientific world views". Theories about the subject matter of the disciplines in which we work are embedded in (scientific) world views which direct the way in which theoretical

T.S. Kuhn (1970) speaks of paradigms as "... changes in world views". 
problems are formulated and determine the type of "hunches" or conjectures that are regarded as acceptable points of departure for the explanation of the "facts". Interestingly enough, these hunches are often embodied in metaphorical language which provides a first intuitive level of access to the structure to be theoretically captured and explained. They also prescribe what will be regarded as the solution of the theoretical problems that become visible within the parameters set by some theoretical framework. So a theory and its way of looking at the world determines what theoreticians see and what they think are the problems to be solved, and to some extent even dictates the acceptable solutions.

What does this have to do with a Christian perspective? Or, reformulated: how do we confess Jesus Christ, our Lord, in scholarly work? Mere recognition of the theory-ladenness of facts is inadequate to show that a religiously determined world view determines the way we see the world. That would require more argument, an argument thoroughly worked out by Roy Clouser in his book on the Myth of Religious Neutrality of Scientfic Theories (1991) with which I concur. Clouser states (1991:66):

Finally, recognizing the distinctiveness of perspectival theories is important because it allows us to notice how theories of reality pervade the concepts and theories of the sciences devoted to a particular aspect and are not confined only to philosophy. In fact ... It is through theories of reality that the influence of religious belief is conveyed to scientific theories: scientific theories necessarily presuppose an overview of reality, while overviews of reality necessarily presuppose some religious belief. Religious belief ... [r]egulates overviews of reality directly, and through the mediation of such overviews regulates scientific theories indirectly.

The deepest religious or faith commitments of a scholar enter into her theoretical work through the mediation of a (scientific) world view with its embedded philosophical assumptions about the subject matter.These philosophical assumptions are about the fundamental structure (order) of the world and imply assumptions about the nature of this order or structure. They are often embedded in theoretical notions that purport not to require any further grounding. Such notions Clouser claims are "religious" claims. His definition of "religion" deviates from the common everyday understanding in which it designates a restricted sacred area of human life in distinction from the profane or the secular. Clouser (1991: 21-23 ) defines religious belief as "... a belief in something(s) or other as 'divine' or ... a belief concerning how humans come to stand in proper relation to the divine". The "divine" is characterized here as that which can exist independent of anything else. When philosophical assumptions of theories harbour assumptions of this kind, they are regarded as "religious". Metaphorical language and models often mediate these 
religious convictions. Christian scholarship implies critically weighing and assessing such assumptions and exposing their ideological or mythical nature.

This means that the central confession of Jesus Christ as Lord and the defense of faith requires careful scrutiny of theories and scholarship in the realm of the academy. The way we proclaim Christ in the academy is in witnessing to the fact that the fundamental assumptions at work in theories need to be in line with a (scientific) world view which honours the unity and diversity of God's creation, the claims of God's Word in Scripture and the fellowship with the risen Christ. Such a testimony needs to attest to the recognition of the fallenness of human life and creation and the total renewal made possible through Christ's death and resurrection.

One of the most pivotal of these philosophical issues is the understanding of the notion of law/order, limits and/or boundaries underlying the dominant theories in a discipline. Having said this, one needs to recognize that these insights are not new, certainly not earth-shattering, and not insights common only to Christian approaches to the special scientific disciplines. Moreover, although many will agree that the notion of order is a central and contentious issue in post-modern discussions in most disciplines, the recognition that this issue is "religious" in nature or that philosophical presuppositions reveal religious choices will be contested by many who are willing to concede the former point. One of the aspects of these sets of philosophical questions and the challenges it poses to Christian scholars I propose to highlight briefly under the following two headings:

- Raiders of the lost universal or the endless search for the elusive universal (with apology to Stephen Spielberg); to which Christian scholars are called to respond with some

- lighthearted philosophical (theoretical) storytelling (with gratitude to Calvin Seerveld).

\section{Raiders of the lost universal}

Common to most traditions in philosophy has been some approximation of the notion that the world we live in is conditioned or transcended by a reality which, in some way or other, is as present in the world we live in as in the actual experiences of everyday. About the nature of this reality there are differences of opinion. Yet the recurring recognition that some sort of order or structure is basic to reality surfaces intermittently through the history of philosophy and the disciplines, and is also true for everyday life experiences. This notion, in some form or other is also present in 
science and theoretical accounts of the structure of the world. If one takes developments in the philosophy of science as indicators, then it is soon clear that this problem is as prevalent in this area as it is prevalent in the various disciplines and in post-modern culture. Developments in philosophy and philosophy of science are a litmus test of the movements taking place in the various disciplines. One such a development is the issue concerning the nature of law/order which regulates the world we live in. So for example in the history of physics one could find diverse interpretations of the structure of atoms and their orderly interaction. Some would argue these atoms actually do exist (scientific realism); others would say that they are just necessary fictions which scientists use like scaffolding until a theory is proved (instrumentalism) - others would contest that terms like "atom" refer to anything that really exists but are mere terms or names (nominalism) we give to things; still others would argue that these names and what they refer to are mere social conventions (conventionalism). These views in turn are closely related to basic philosophical views about the nature of order, limits and or boundaries in reality.

Most fundamental turns in the history of philosophy are attempts at localizing these limits of reality and human life in reality itself, in either the subject or the object. The pivotal issue at the centre of the "turns" in philosophy of science appears to be diverse articulations of this locus of order. If Christian philosophy wants to shed light on this issue so central to the heart of theorizing, it needs to develop a dynamic understanding of the notion of law, order, limits and boundaries and the way such an understanding could inform the discussions concerning scientific realism and the end(s) of philosophy.

Most authors shy away from postulating some accessible independent, conditioning universal order because of the problems surrounding the traditional view of linguistic or ontological universals and essentialism. The argument against essentialism and the recognition of some form of universals seems to run as follows: the only access one has to this reality is language and the communities that form and change languages - therefore, although such a reality might exist, science can have no real access to it. But the paradox is that in each historical turn in the development of the sciences, some or other aspect of reality is declared ultimate and the final locus of order, whereas the issue of the nature and existence of such order is often either taken for granted or not given any account of. It is especially the preoccupation with scientific change and the obvious instability of scientific concepts that has brought about renewed interest in the relationship of stability and order on the one hand, and changing perceptions and concepts on the other (cf. Collins, 1985; Nersessian, 1984a \& 1984b; 1991a \& 1991b; 1992), not to men- 
tion "chaos theory" as a concealed search for complex order (Bohm, 1980; 1992).

It is this perennial search for the elusive universal that surfaces in each of the "turns" in either philosophy or science which "turn" up with monotonous regularity in subject-related literature. The Positivists' Logicistic turn is followed by The Linguistic turn (or language as metaphor for reality and knowledge) which can be summarized in Wittgenstein's dictum: the limits of my language mean the limits of my world. Ordinary language philosophy can be associated with the view that the structure of reality is a projection (not a reflection!) of the grammar of language, so that the investigation into how words are used is simultaneously an enquiry into ontology (Thompson, 1983:24) and a philosophical notion duly appropriated by Peter Winch in his Idea of a Social Science and Its Relation to Philosophy (1967), and in many other disciplines. These turns were followed by the Historical/Historicist, Sociological, Hermeneutical and Cognitivist turns. All these "turns" seem to be bound in their point of departure to an epistemological position which could best still be described as that of modernity, i.e., anchored in the Enlightenment ideal of the subject-object divide and the belief that objective rational knowledge can be acquired, yet attempting to approach this rational objective knowledge via the medium of the knowing subject. Each one of the "turns" in philosophy and philosophy of science participates in the quest for order and the perennial search for the elusive "universal". Moreover, these turns in philosophy and philosophy of science either represent or reflect similar searches in scientific theories.

Perhaps this is best illustrated in the Logicistic turn brought about by neo-positivism: the Logical Positivists of the Vienna Circle were convinced that what scientific disciplines needed was one common language - the language of physics, a language cleansed of all possible religious and metaphysical debris. So convinced were these enlightened scholars that a science free of metaphysics and theology ought to be developed, that they set out on a purifying, clarifying, sanitizing and cleansing expedition of all the sciences. And like good Dutch housewives they would be satisfied only when every speck of metaphysical dust and theological cobwebs had been cleared from science. The method they proposed for this "spring cleaning" was logical analysis. The Logicistic turn emphasized the use of logical methods in the process of the justification of theories and the characterization of rationality and truth. Logical Positivists argued that by sterilizing and sanitizing language, by removing all metaphysical and theological elements, they would provide science with a neutral set of formulae that could be manipulated by formal logic (Neurath \& Neurath, 1973:306). This was all in the service of the spirit of enlightenment, as they formulated it. It would, so they 
argued, be possible to reduce most of the laws in the various fields to physical laws. This form of reductionism aptly called "nothing buttery ..." by Donald MacKay (1974) was a kind of "anorexia" of the sciences. Who in his right mind would follow suit? According to reliable sources and by their own recognition, just about every single discipline in the academy!

Did this strange philosophy matter? Well, to them it did, enough to embark on a crusade of providing both the sciences and society with intellectual tools for the conscious reshaping of life and society. Did they provide the history of philosophy with light? Well, if it is taken into account that this understanding of the nature of science was the dominant approach for at least five decades and that most natural and social sciences by their own admission based their epistemology on this approach, then it is clear that this philosophy mattered.

During the course of the sixties this preoccupation with language had a concomitant "turn" to the history of consecutive language games, forms of life and/or scientific paradigms, the so-called Historicist turn (cf. Kisiel et al., 1974) represented by Hanson, Toulmin, Polanyi, Kuhn, Feyerabend, etc. The historicist emphasis led to a recognition of and sociological emphasis on the role of the scientific community as initiator and sanctor of the legitimacy of scientific knowledge and language. With the Historicist turn came a consciousness of the significant role of theoretical frameworks in science and the understanding that these frameworks are bound to metaphysical and other assumptions. About the question of how the regularities, the limits that theories tried to explain, were to be localized, differences of opinion remained, but this development showed a strong leaning toward a Kantian understanding where the laws are the product of human intellect. Did this philosophy matter? There is not a single discipline represented in the academy that did not buy this development. The notion of a "paradigm" which has become part and parcel of everyday parlance is probably one of the most prominent legacies of this movement but with these insights both the positive and negative dimensions of a rethinking of rationality and relativism were ushered into the building of the academy.

The Historical and the Sociological turn (Brown, 1984:3-40) with its variations of conventionalism and constructivism is perhaps best represented in the work of Richard Rorty and in epistemolgy in the The Strong Programme of Sociology of Knowledge of the Edinburgh School, and Harry Collins' (1985) constructivism or so-called Empirical Programme of Relativism, which locates the regularity of the world in the regularity of our institutionalized beliefs that impose themselves on the world ... the locus of order is society (Collins, 1985:148). This perennial search for the elusive universal reaches a dead-end in post-modernism, 
characteristically typified in the phrase "The unbearable lightness of being 'postmodern'”, by Gary John Percesepe in Christian Scbolars' Review in 1990. It is exactly the heavy foundationalist assumptions that are interrogated by post-modernism (Percesepe, 1990:125). Percesepe (1990:129) claims the mark of the post-modern is "the stark refusal to cultivate a nostalgia for the unattainable", and the unattainable is clearly the discovery of foundations for our knowledge or of being in the world coupled with any form of essentialism (cf. Fraser \& Nicholson, 1988) and the nostalgia for the whole and the one - the total (Lyotard, 1984:81).

What is attractive and compelling in this article is the author's insistence that the problems that plague Western society and its intellectual pursuits are not only to be attributed to recent developments in post-modern philosophy, but should be recognized for what they are, that is, the endproduct and historical outcome of philosophizing and theorizing which systematically undermined and questioned the foundations of the available meta-narratives of the West. Percesepe suggests that these meta-narratives have always been exceedingly fragile. And we have been masters at both declaring these narratives as total and true and suspiciously undermining the foundations on which they were built. So the questioning of the foundations has been part and parcel of the history of Western philosophizing since long before the advent of postmodernism. Percesepe warns us to try to refrain from "cursing the darkness", or to name the darkness with but one name, "postmodernism". Moreover, he points clearly to the fact that the darkness nestles deeply within all of us, and has always been part of our individual and communal intellectual pursuits.

It is possible to argue that the "malaise of modernity" (Taylor, 1991) is a very special case of darkness, but this presupposes the assumption that what preceded modernity was light or gradations of light - the light of reason, perhaps ... ? It is exactly against this light that post-modernism has rebelled. It is exactly this notion of rationality that post-modernism has called into question (Rouse, 1991). After having given up on the possibility of arriving at Truth and having concluded that the long-soughtafter foundation is groundless, what remains is only the dialogue of the philosophical community in which we are left to console one another with the conversation about/at (?) the end(s) of philosophy (Percesepe, 1990: 120).

In post-modernism philosophy finds itself not only at the end of an age; but post-modernism also signals a turning point in the "turns". This development is not the essence of darkness, to use a metaphor the postmodernists would be loath to accept, but the culmination of a historical process in which we have allowed human intellectual arrogance to 
eclipse the clear and lucid light of God's revelation in His creation and in Scripture, which proclaims that God is the Lawgiver and not our reason, senses, language or social community, how tempting this might be to believe - and how tempted we are to allow these derailing insights uncritically to inform our theorizing and our educational stories.

I do not think one needs philosophical sophistication to realize that these developments represent both honest intellectual struggles that have succeeded in getting hold of rays of light, but also that in these struggles the pockets of darkness have not been eradicated. Whether one formulates the central issue at stake here as "nominalism" or "realism" is to some degree immaterial. These developments represent the search for some common denominator or ultimate ground of human knowledge - the search for the elusive "universal" whether on the ontological, epistemological or linguistic level.

The "turns" I have briefly mentioned are all attempts at giving some account of the stable/changing order in the world and of our human capacity to know and name this order. They do not recognize sufficiently that objectivity and certitude cannot be anchored in either subject or object, but needs to be anchored in the common universal conditioning order of God's law for creation which conditions the existence, experience, knowledge and naming of both subject and object. And it is to witness to this covenantal call that Christian scholars, and specifically Christian philosophers, are called to be lighthearted story tellers.

In spite of the philosophical and historical baggage which formed part and parcel of Herman Dooyeweerd's Transcendental Critique of Theoretical Thought (1953), I found his analysis of a ground idea and idea of law one of the most illuminating insights which showed a way to deal with critical issues in the area of politics, social science and philosophy. The notion of law has been one of the most helpful insights I could gain from Dooyeweerd and Vollenhoven's philosophy. This was the "key" of Dooyeweerd's thought, which opened up the understanding of his philosophy for me, but also opened up clear inroads into the understanding of the world. But, I must add, a simple and very pre-theoretical chapter in van Riessen's work, Wijsbegeerte (1970), opened the insight to me that God's law is his covenantal law, the law which binds Him to His creation and envelops our creation through the bond of His love. This law not only sets the limits for created reality, but is also the bond of God's faithfulness to His creation 


\section{Lighthearted philosophical storytelling (2 Cor. 4:6)}

I do not think I need to explain what I mean by "lighthearted". If God's revelation speaks to us through the light of His Word and His creation, then we are called by Him who sent the Morning Star to banish the darkness also of human hearts, to work diligently at understanding the structure of the world $\mathrm{He}$ has called us to profess. Lighthearted philosophical storytelling requires philosophical tools in order to unmask the implicit dark philosophical assumptions at work in the theories to which we expose our students. How do we steer their intellectual development in the direction of the light and away from the pockets of darkness so prevalent in the philosophical heritage of the West? How do we discern and distinguish light from darkness in the theories and textbooks we require our students to read with care? Without a Biblical vision, systematically articulated in a Christian philosophy, our students are not adequately equipped to deal with the issues pertaining to light and darkness present in their theoretical apparel. Without this equipment they will not learn to do justice to the rays of light and darkness present in the plurality of theories and perspectives they are confronted with.

It is clear that convincing answers to these questions need to steer a course between "flabby" (Booth, 1986) pluralism which assumes that mere knowledge of a plurality of perspectives automatically assures immunity against the darkness, and "wild" (Bernstein, 1987) pluralism which rejects any possibility of communication between different positions and therefore gives up on the call to professing Christ even before we have started. I propose that the development of critical philosophical skills coupled with a responsible analysis of the theoretical infrastructure of theories requires solid philosophical grounding of both teachers and students and requires the recognition of philosophy's legitimate place in the curriculum. Why? Because philosophical systems and frameworks embody humankind's vision of what constitutes order and meaning in human life and reality, and because these systems reflect the deepest answers to the human predicament. Moreover:

The philosophy and historiography assumed in the classroom teaching of any subject acts like a preemptive strike upon the student, because much as your mother tongue, which you learn even before you can speak, determines your world of conversation, so philosophy veritably functions as a schooled memory, and becomes the reservoir shaping the student's ideas and conceptual world (Seerveld, 1990:81).

Responsible scholarly work requires a testing of the "spirits" in order to take every thought captive in obedience to Christ. If academics are not able to do this, we need to devise creative and imaginative ways of 
Faculty development that could make this possible. The discernment required of a Christian scholar implies a sensitivity to the spirit that motivates and drives the deep assumptions of theories, and an ability to identify those notions that lead to a distortion or perversion of God's good creation.

Christian scholarship points to the need for a systematic Biblical philosophical framework thoroughly rooted in an understanding of the history of philosophy and one's own discipline. Once a student has understood that observation and the description of facts are thoroughly theory-laden, and that theories with their norms and patterns and standards of order are decisive determinants of data and facts, then (s)he comes to realize that the rich diversity of creation is always more encompassing than our theories are able to explain. There are always many more theories available to explain the orderly character of reality than only one. With this recognition inevitably comes the recognition that Christians have to develop criteria to judge the claims of pluralism and the plurality of theories. The perceptive student will soon ask: Which theory is the right and true theory, and the Christian student will also be asking which theory is compatible with the confessional commitments professed at a Christian university college. This is the crucial point in the practice of Christian scholarship. This is not just the task of Philosophy. It requires hard work at the level of Biblical foundations, hermeneutics and world view understanding. It also requires special scientific knowledge which is sensitive to the presence of foundational issues and, in the final instance, it requires systematic attention to the philosophies of the special scientific disciplines.

\section{Bibliography}

BERNSTEIN, RICHARD J. 1987. The varieties of pluralism. American Journal of Education, 95(4):509-525, Aug.

BOHM, DAVID. 1980. Wholeness and the implicate order. New York : Routledge.

BOHM, DAVID. 1992. Postmodern science and a postmodern world. (In Jenck, Charles, ed. The post-modern reader. London : Academy Edition. p. 383-391.)

BOOTH, WAYNE C. 1986. Pluralism in the classroom. Critical Inquiry, 12(3):468-479, Spring.

BROWN, J.R., ed. 1984. Scientific rationality: The sociological turn. Dordrect : Reidel. HENRY, CARL F.H. 1988. The Christian scholar's task in a stricken world. Christian Scholar's Review, XVII:4, June.

COLLINGWOOD, R.G. 1940. An essay on metaphysics. Oxford: Oxford.University Press.

CLOUSER, ROY A. 1991. The myth of religious neutrality. An essay on the hidden role of religious belief in theories. Notre Dame : University of Notre Dame Press.

COLLINS, H.M. 1985. Changing order. Replication and induction in scientific practice. Chicago : University of Chicago Press.

DOOYEWEERD, HERMAN. 1953. A new critique of theoretical thought. Vol. I, 1955 vol. II and vol. III, 1957. Amsterdam : Paris. 
FRASER, NANCY \& NICHOLSON, LYNDA. 1988. Social criticism without philosophy: An encounter between feminism and postmodernism. Theory, Culture and Society, 5:373-394.

KISIEL, THEODORE \& JOHNSON, GALEN. 1974. New philosophies of science in the USA: A selective survey. Zeitschrift fur Algemeine Wissenschaftstheorie, $\mathrm{V}(1): 138-191$.

$\mathrm{KOCH}$, SIGMUND. 1981. The nature and limits of psychological knowledge. Lessons of a century qua 'science'. American Psychologist, 36(3):257-269.

KUHN, T.S. 1970. The function of dogma in scientific research. (In Brody, Baruch A., ed. Readings in the philosophy of science. New Jersey : Prentice-Hall. p. 356373.)

KUHN, T.S. 1973. The structure of scientific revolutions. (2nd enlarged ed.) Chicago : University Press.

KUHN, T.S. 1974. Second thoughts on paradigms. (In Suppe, F. The structure of scientific theories. Urbana : University of Illinois Press. p. 459-499.)

LASZLO, E. 1972. Introduction to systems philosophy: Toward a new paradigm of contemporary thought. New York : Harper \& Row.

LYOTARD, JEAN-FRANCOIS. 1984. The postmodern condition: A report on knowledge. Minneapolis : University of Minnesota Press.

MACKAY, DONALD. 1974. The clockwork image. A Christian perspective on the sciences. Downers Grove : IVP.

NERSESSIAN, NANCY J. 1984a. Science and philosophy. Faraday to Einstein: Constructing meaning in scientific theories. Dordrecht : Nijhoff.

NERSESSIAN, NANCY J. 1984b. Either/or: The creation of scientific concepts. Studies in the History and Philosophy of Science, 15(3):175-212.

NERSESSIAN, NANCY J. 1991a. The cognitive sciences and the history of science. (In Critical problems and research frontiers in history of science and history of technology, 30 October - 3 November 1991. Madison, Wisconsin. p. 92-115.)

NERSESSIAN, NANCY J. 1991b. Discussion: The method to "meaning": A reply to Leplin. Philosophy of Science, 58(4):678-686, Dec.

NERSESSIAN, NANCY J. 1992. How do scientists think? Capturing the dynamics of conceptual change in science. (In Giere, R., ed. Minnesota Studies in the Philosophy of Science. Cognitive Models of Science, vol. X-V. Minneapolis : University of Minnesota Press. p. 3-44.)

NEURATH, OTTO \& NEURATH, MARIE. 1973. Empiricism and sociology. Chapter 9: "Wissenschaftliche Weltauffassung der Wiener Kreis". Dordrecht : Reidel.

NEWBIGIN, L. 1996. Foolishness to the Greeks. The gospel and Western culture. Grand Rapids : Eerdmans.

PERCESEPE, GARY J. 1990. The unbearable lightness of being postmodern. Christian Scholar's Review, XX(2):118-135, Dec.

PLANTINGA, ALVIN. 1983. Advice to Christian philosophers. Inaugural address as John A. O'Brien Professor of Philosophy, November 4, 1983. Notre Dame, Indiana : University of Notre Dame,.

POPPER, KARL. 1972. The bucket and the searchlight. (In Popper, Karl. Objective knowledge. An evolutionary approach. Oxford : Clarendon Press. p. 346-347.)

ROUSE, JOSEPH. 1991. The politics of postmodern philosophy of science. Philosophy of Science, 58:607-627.

SPRAGENS, T. 1973. The dilemma of contemporary political theory; Toward a postbehavioral science of politics. New York : Dunellen.

SULLIVAN, T., THOMPSON, K., WRIGHT, R. et al. 1980. Social problems. Divergent perspectives. New York : Wiley. 
SEERVELD, CALVIN. 1978. A cloud of witnesses and a new generation. Vanguard, Nov.-Dec.

SEERVELD, CALVIN 1990. Concluding theses. (In Roose, John W. \& Pierson, George N., eds. Philosophy in the Reformed undergraduate curriculum. Chicago. Palos Heights : Trinity Christian College. p. 81.)

TAYLOR, CHARLES. 1991. The malaise of modernity. The Massey Lecture Series. Concord, Ontario : Anansi.

THOMPSON, JOHN B. 1983. Critical hermeneutics. A study in the thought of Paul Ricoeur and Jurgen Habermas. Cambridge : Cambridge University Press.

VAN RIESSEN, H. 1970. Wijsbegeerte. Kampen : Kok.

WINCH, PETER. 1967. Idea of a social science and its relation to philosophy. New York : Humanities Press.

WELTMAN, JOHN J. 1973. Systems theory in international relations. A study in metaphoric hypertrophy. Lexington : Heath.

WOLTERSTORFF, NICHOLAS. 1984. Reason within the bounds of religion. Grand Rapids : Eerdmans.

Key concepts:

Christian philosophy

religious neutrality

scholarship

Kernbegrippe:

Christelike filosofie religieuse neutraliteit wetenskap 